Strategic planning activity, middle manager divergent thinking, external stakeholder salience, and organisational performance: A study of English and Welsh police forces. 


\title{
Strategic planning activity, middle manager divergent thinking, external stakeholder salience, and organisational performance: A study of English and Welsh police forces.
}

\begin{abstract}
Although strategic planning is mandatory in the UK police force its usefulness is questioned due to the link between planning and performance in the public sector. Moreover, how middle management and external stakeholders influence the planning process needs deeper exploration as part of the planning-performance relationship. Data from UK police force middle managers reveals an indirect influence of strategic planning on performance mediated by the divergent activity of higher-level middle managers, as well as the salience of external stakeholders. The impact of higher and lower level middle managers in the strategy process and external stakeholders is discussed with implications for future studies.
\end{abstract}

Keywords: Strategic planning, middle managers, divergent activity, stakeholder salience, public sector, police forces, organisational performance. 


\section{Introduction}

In common with other United Kingdom public sector organisations, English and Welsh police forces have seen changes commonly referred to as New Public Management. These have included the introduction of devolved management structures and an increased focus on measuring performance against published objectives. Following the introduction and then widespread adoption of management by objectives principles in the 1980s (Lubans and Edgar, 1979), forces began to produce longer range organisational plans. This followed a trend of introducing strategic planning techniques in public sector organisations (Ferlie and Ongaro, 2015) which aimed to improve goal consistency and continuity of effort (Bryson et al., 2009; Bryson et al., 2018). The government formalised this in 1998, requiring police forces to publish 3-year 'strategy plans'. Despite the long term experience of formal planning, doubt has been expressed over the effectiveness of strategic planning in police forces. In a wider review of strategic management tools in the public sector, Williams and Lewis (2008 p. 654) suggest it is 'questionable whether private sector models are easily implanted or indeed helpful in public management practice'. The multiplicity of stakeholder relationships, varied perspectives on organisational performance, and political influences, can result in a complex mis of views about purposes and priorities. Therefore a more detailed insight into the role of that strategy plays in public services is required (Boyne and Gould-Williams, 2003).

There is a scant empirical assessment of the influence of planning processes on policing performance in particular, and on organisational performance in the public sector more generally (Haberman and King, 2011). The proposition that strategic planning is, 'a ritual like Quinn's rain dance' (O'Regan and Ghobadian, 2007) with little relevance to the 'unique' context in which policing operates is yet to be explored. Conversely, planning might play a valuable role in accounting for stakeholder needs in determining strategic direction for a force. This study is one of very few empirical examinations of the intra-organisational role that strategic planning plays in policing, and more widely the UK public sector. It seeks to explore what Elbanna et al. (2016) suggest is an 
extremely valuable contribution to more nuanced strategic planning research: assessing the influence of different stakeholder groups on the planning and implementation relationship.

Public services scholars are reflective of long-running scepticism about the effectiveness of strategic planning's effect on performance (Mintzberg and Waters, 1985), despite the wide spread practice-based use of strategic planning or proxies for it such as annual budgeting. In the public sector context, a study of Welsh local government bodies, (Andrews et al., 2009) identifies a supportive but not significant role for strategic planning. At a wider level Rudd et al. (2008) suggest there is little consensus about how strategy-making takes place, suggesting any study of planning needs to account for how such processes influence the perceptions and activities of managers.

Research examining the impact of managers on strategy development has been predominantly based on the assumption that the formal leader, and top managers or 'upper echelons' in organisations, are the primary determinants of strategic direction (e.g. Finkelstein \& Hambrick, 1996, Hambrick and Mason, 1984, Ismail, 2016). Managers in the middle of the organisation are portrayed as implementers, or sometimes blockers of new strategy (Guth and MacMillan, 1986). Contemporary accounts in public management recognise middle managers as actors in the development and deployment of strategy (Burgess and Currie, 2013), as part of their role in the achievement of organisational goals (Hogan et al., 2011). The important role played by middle managers has considerable heritage (Likert, 1961), and this position between operational and executive levels suggest they have a unique perspective on strategic issues. Middle managers can therefore be the drivers as much as the recipients of strategy (Mantere, 2008). It is important therefore to assess what involvement middle managers have in strategy development in a context where formal strategic planning has become deeply embedded. Building from Miller (1997) it will be important to ascertain if the rationality of planning as a purposeful and ongoing activity influences organisational 
performance by enabling middle managers to develop new and innovative strategic ideas by dealing with foreseeable eventualities in advance.

The importance of external stakeholders to public sector organisations and cooperation with other agencies is an important aspect of policing (e.g. collaboration with Community Safety Partnerships, considered in this study). Similarly, Greenley et al. (2004) underscore the importance of companies that focus on the demands of customers, competitors and employees exhibit innovation and learning in strategic planning. However, how strategic planning facilitates working between organisations and external stakeholders is not clear. Using the policing context enables us to single out a particular stakeholder group with whom forces work and test if strategic planning influences this relationship.

We begin with the theoretical foundation for the paper and then develop hypotheses concerning the relationship between strategic planning activity, external stakeholder salience, middle manager divergent activity and organisation performance. The research design, sampling strategy and survey instrument are then explained before the model is analysed using Structural Equation Modelling (SEM) and the partial least squares (PLS) method. Results are summarised and implications are presented for scholars and law enforcement practitioners.

\section{Theoretical foundation}

The desire to explain differences between the performance of organisations and identify the sources of success is central to the study of strategy (Rumelt et al., 1994). In order to explain such differences in performance, research into strategy has moved from it being seen as the result of rational choices of top management (c.f.Ansoff, 1965) into complex processes inside organisations (Ezzamel and Willmott, 2007). This processual school of strategy grows largely from the work of Mintzberg (1994) and research which questions deterministic accounts of strategic planning which is 
underpinned by the theoretical separation of strategy formulation from its implementation (Mintzberg and Waters, 1985). The processual perspective has also set the basis for more recent work in Strategy as Practice (Chia and MacKay, 2007).

Strategy as process recognises that planning activities involve practitioners at all levels of the organisation. It highlights managers' motivations and constraints around intended actions, including psychological constraints such as bounded rationality (Simon, 1963). Strategy development becomes '...a matter of social learning, that is, managers and others in the organisation learning how to adapt to a changing environment' (Wooldridge et al., 2008 p. 1193). Processual views of strategy focus on the realities for individuals working in organisations to expose the constraints and limitations which can influence strategic actors allowing a more comprehensive representation of organisational activity. This enables the strategy researcher to look behind the formal roles and processes established in the organisation to see how they influence deeper motivations and influences on those involved.

\subsection{Strategy, middle managers and divergent thinking}

Theorists building on Burgelman (1983) argue that middle managers are uniquely positioned to play a key role in crafting the process of strategy. Wooldridge and Floyd (1990) and Floyd and Wooldridge (1992) find a relationship between the involvement of middle managers in developing strategy and organisation performance. Why middle managers choose to engage in this activity is not fully understood (Wooldridge et al., 2008), but Elbanna et al. (2016 p. 1022) suggest a good 'prima facie' case is made for middle manager involvement in the strategy process being important in the context of public services.

Wooldridge, Floyd and Schmid (2008), in a review of middle manager strategic activity studies, conclude that environmental, organisational and individual factors all have a part to play. In 
a public services context (the UK National Health Service - NHS) Currie (1999; 2000) suggest there are additional, different factors constraining the strategic activity of middle managers. Currie concludes that the top-down nature of planning in the NHS constrains the divergent activity of managers. He also proposes that the performance structure imposed by the government, and role ambiguity originating from organisational change constrains managers from acting strategically (Currie and Procter, 2005). The conclusion of Currie and Procter (2005) about the impact of government policy raises an important question about how stakeholders outside the organisation may influence middle manager activity and organisation performance.

\subsection{Strategic planning and stakeholder influence}

Although various definitions of strategic planning exist, (Bryson, 2004) argues that strategic planning is best understood as a set of concepts, procedures and tools which organisations use in the determination of their overall strategic direction including the resources required to achieve these aims. These techniques are not used in a vacuum, and the role of stakeholders in a public services context are important to consider when decisions are getting made (Currie, 2000; Lee et al., 2018). In particular public services managers use strategic planning to take account of different perspectives and needs of stakeholders with whom they interact to deliver organisational aims (Bryson et al., 2009).

Two broad views can be summarised from the literature when it comes to defining stakeholders in the context of planning. First, there is a narrow view focusing on the people or groups 'on which the organisation is dependent for its continued survival' (Windsor, 1992 p. 91), or 'those who have the power to directly affect the organisation's future' (Bryson, 2004 p. 22). These are primarily those stakeholders who have legitimacy (e.g. owners, employees, direct suppliers). Second, a broader view will include 'any group or individual who can affect or is affected by the achievement of the organisation's objectives' (Freeman, 1984 p. 46). Thomas and Poister (2009) suggest the 
broader definition is more appropriate for public sector organisations because of the multiple and varied stakeholder influence. Hence we adopt Freeman's definition in the context of this study due to the multiplicity of stakeholders which policing bodies must deal with.

Greenley et al. (2004) conclude that companies who focus on addressing the variety of demands from customers, competitors and employees exhibit more innovation and learning in strategic planning. Conversely, firms paying little attention to their stakeholders display low levels of innovation. In seeking some clarity about how to account for diversity of stakeholders, Mitchell et al. (1997 p. 854) propose the concept of salience as 'the degree to which managers give priority to competing stakeholder claims'. This definition provides a means for assessing how managers decide between competing stakeholders and is used by Agle et al. (1999) who, in a study of government salience, also suggest stakeholders internal to the organisation may influence divergent activity in a different way to those who are external to it.

\section{Hypothesis development and conceptual framework}

Strategic planning, with its emphasis on formal processes, data gathering, rational analysis, and objective target setting, remains the predominant way in which large commercial and public organisations develop strategy (Whittington and Cailluet, 2008). Despite its practice-based popularity there is no consensus about how formal strategic planning impacts organisation performance. Brews and Purohit (2007) review previous strategic planning research and conclude, with proper construct measurement and proper controls in place, positive formal planning/performance relationships are consistently noted. However, Falshaw and Glaister (2006) find no support for a direct link between the formality of planning and financial performance in a sample of UK manufacturing firms. O'Regan and Ghobadian (2007) also find no direct link in a sample of UK small and medium-size enterprises but suggest how seriously firms approach planning 
may be a contingent factor. Hence, we firstly hypothesise the following association between planning and performance:

H1. There will be a positive relationship between strategic planning activity and police force organisational performance.

Rudd et al. (2008) criticise the traditional bi-variate nature of studies in the area of strategic planning and propose that links to performance are indirect and may be mediated by other factors. Using a survey of top managers in medium/large UK manufacturing organisations, they conclude that organisational flexibility acts as a mediator in the planning/performance link. Strategic planning processes, with their basis in rational decision making from evidence, engender confidence in middle managers that new ideas will be received and dealt with objectively by top management. However, where managers perceive the strategic planning process results in an organisation's future direction is imposed on them it then leaves little room for flexibility. It appears the perception of their ability to influence is suppressed (Floyd and Wooldridge, 1992). Separately, Currie and Procter (2005) find that government policies increase role conflict for public sector managers whilst Greenley et al. (2004) argue that managers' perception of stakeholders can negatively influence the degree of learning and innovation in strategic processes. Managers therefore face competing demands and expectations due to a lack of time or resources, or their inability to prioritise can result in role conflict and ambiguity (Floyd and Lane, 2000). If role conflict and ambiguity increases then managers' perceptions of their ability to influence the organisation is constrained. Managers can therefore be expected to deal with this tension by reducing or simplifying demands and expectations on them.

Stakeholder salience (Mitchell et al., 1997) is the manager's perception of the degree to which a stakeholder impacts on their work. It is a factor of the power, legitimacy and the urgency of a particular stakeholder's demands as perceived by the manager. To summarise this complex picture we follow the same line of thinking as (Elbanna et al., 2016) who show how stakeholder uncertainty 
influences the relationship between formal strategic planning and strategy implementation success. In the context of this study the stronger the salience of external stakeholders the less influence a middle manager will perceive about their ability to alter the status quo within the organisation. Hence,

H2. External stakeholder salience will mediate the relationship between strategic planning activity and force organisational performance.

Middle managers make a significant number of decisions about the use of resources in organisations and these can, over time, get adopted into the planned strategy. This divergent activity is supported by Lovas and Ghoshal (2000) in their case study of General Electric. They conclude that autonomous, as well as induced, initiatives in an organisation are important for long-term success. Grant (2003) also supports this conclusion about the role of semi-autonomous behaviour of middle managers in developing strategy, terming it 'guided evolution'. Divergent activity of middle managers can lead to better information and ideas, with particular insight into the strategic issues of the organisation as an input to the planning process.

One particularly important function of strategy is the performative processes 'challeng[ing] the 'dominant' logic of the firm ... spark[ing] the development of new capabilities' (Pappas and Wooldridge, 2007 p. 324). Bettis and Prahalad (1995) argue that dominant logics lead managers to focus on certain information and give less attention to other cues for change, thus preserving the status quo. Middle manager divergent activity influences organisations in two ways. First, Dutton and Ashford point to (1993) 'issue selling' as a critical activity of middle managers in the early stages of strategic decision making. This is because they 'have their hands on the pulse of the organisation and are closer to customers and stakeholders' (Dutton et al., 1997 p. 407). Championing alternatives is therefore an activity (Floyd and Wooldridge, 1992) focused upward to top management, and is an important way in which middle managers feed new ideas upward and contribute to the organisation's strategic direction. Second, divergent activity encourages behaviour which deviates from the 
organisational norm by facilitating adaptability. Burgelman (1983 p. 67) argues that strategic development requires, 'interlocking autonomous strategic initiatives of individuals at operational and middle levels, and an experimentation-and-selection at corporate level.' Furthermore, Andersen (2000) also finds no direct link between formal strategic planning and middle managers being more autonomous in their working. It may therefore be the case that the depth of adoption for formal planning and the use of analytical procedures for assessing the external environment yields deeper and more coalesced insight into stakeholder needs. Therefore, we hypothesise the following;

H3. Middle manager divergent activity, a second order latent variable comprising (H3a) championing alternatives and (H3b) facilitating adaptation, will mediate the relationship between strategic planning activity and force organisational performance.

In summarising the relationship between the hypotheses we use a theory testing approach to investigate the role of strategic planning activity, external stakeholder salience, and middle manager divergent activity on force performance as shown in Figure 1.

\section{Research design}

\subsection{Sample frame}

Policing in England and Wales is carried out by a large number of separate and largely autonomous forces which vary in size, approach and policing problems experienced. They share a similar mission, structure, regulatory framework and strategic planning requirement. For 18 years they have been legally mandated to strategically plan, so the presence of this uniformity of planning requirement is very pertinent for this study. We expect that planning process adherence is likely to have some ingrained impact on the way middle managers operate. We anticipate this context tempers any 'lag effect' from 1998 because of its long-term and continual use. Uniquely, the English and Welsh policing context allows us to measure what we expect will be the varying performative effect 
of strategic planning activity between forces, with this sectoral focus allowing us to control for organisation type and comparable job roles.

[Insert Figure 1 here]

In 2012, the Police Reform and Social Responsibility Act 2011 introduced elected Police and Crime Commissioners (PCCs) for forces outside London. The PCCs do not have the powers of police officers and are responsible for securing effective and efficient policing in their force area. The 41 forces overseen by PCCs are the focus of the study. These 41 'PCC' forces are split into small geographical areas for operational purposes which are generally coterminous with local authority boundaries. ${ }^{1}$ As a result of the Crime and Disorder Act 1998 police managers at force and local area level are required to work together with local authorities and other agencies in Community Safety Partnerships to coordinate effort against crime and disorder. These arrangements, along with the similar planning structures within and around PCC forces, enable valid comparisons across a large enough sample of respondents for statistical purposes.

Each force comprises personnel in clearly defined roles, ranks or grades. Police officer ranks are set by the Home Office and are the same for all forces, which aids between-force comparisons. There has been an increase in number of administrative personnel in management positions in police forces in the past 20 years at all levels apart from chief constable. These 'police staff' managers will often be involved in more specialised work in headquarters departments and units but they have potential strategic influence so we include them in the sample frame for this study. Although the titles of police staff roles are not standard, individuals are able to equate their role with an organisational level. The nine levels are shown in Table 1 with the sample population (middle managers) highlighted.

\footnotetext{
${ }^{1}$ The term Basic Command Unit (BCU) is not been used because, by the time of this study, it was being used differently by some forces.
} 
[Insert Table 1 here]

Middle managers can form a varied group in large organisations like the police forces in this study, and this has led Mantere and Vaara (2008) to propose that there are higher and lower level middle managers. Higher level middle managers (HLMM) are closer to the executive and can exert more influence on organisation strategy through their divergent activity. Lower level middle managers (LLMM) are similar to Floyd and Lane's (2000) definition of operational managers who are more focused on the implementation of current strategy. In hierarchical organisations with a clear chain of command, divergent activity by lower level managers is likely to have less impact on the executive decision makers of the organisation. The large range of hierarchy in English and Welsh police force is a benefit for this study as it permits the testing of this higher/lower distinction for two groups of middle managers for differences which Mantere and Vaara (2008) expect to be present.

In the police force context executive managers are responsible for the performance of the force, middle managers for the work of units or functions at HQ or local level, and supervisors (who may be constables) for the day to day work of operational officers. Applying the definition of middle manager used by Wooldridge and Floyd (1990) suggests that the police officers above supervisor but below executive level should be included in the study.

\subsection{Data collecting procedure}

Letters were sent to the chief constable of each police force in the population asking them to participate, with 17 out of 41 forces agreeing. The sample covers the full range of forces in England and Wales (see Table 2). There was no significant difference between the forces participating and other forces ( $\mathrm{t}=.99$ (two-tailed). Reasons given for not participating included a perception that there was survey fatigue among force managers, possible conflicts with other studies going on in the force, and force policy strictly controlling the number of surveys carried out each year. In 2014 an email 
was sent by the participating force HR Departments to all police officers in their force between the ranks of inspector and chief superintendent, and to all police staff with similar levels of responsibility. This invited respondents to participate in an on-line survey. A follow-up email was sent one week later to non-respondents asking them to participate.

\section{[Insert Table 2 here]}

In total, 742 survey responses were received from a total sample of 4697 potential respondents, which represents an initial response rate of $15.8 \%$ of the middle managers in participating forces (see Table 3). Eliminating outliers and surveys with excessive missing values (55 respondents) a usable sample of 687 responses was obtained resulting in a response rate of 14.6\%, the average for web-based surveys (Jin, 2011). Middle manager subgroups totalled $\mathrm{n}=116(16.9 \%)$ for higher level middle managers (HLMM) comprising superintendents and chief superintendents, and $\mathrm{n}=571(83.1 \%)$ for lower level middle managers (LLMM) comprising inspectors and chief inspectors.

\section{[Insert Table 3 here]}

To evaluate non-response bias as well as to rule out systematic differences between responses received at various stages of the data-collection process, we use analysis of variance to compare sets of responses, including early vs. late responses (Armstrong and Overton, 1977) which found no significant difference by response stage. Common method bias was tested using Harman's singefactor test (Podsakoff and Organ, 1986). The first factor explained 33.17\% of the variance showing it is not significantly influencing the results of this study.

\subsection{Measurement development}

Four constructs formed the nomological network of our structural model in Figure 2. These are force organisation performance (FOP), middle manager divergent activity (MMDA), strategic 
planning activity (SPA) and external stakeholder salience which is operationalised as Community Safety Partnership salience (SALCSP).

The difficulty of forming a meaningful measure of organisational performance (FOP) is a conundrum for strategy research (Venkatraman and Ramanujam, 1986). Boyne and Walker (2010) argue that this is especially complex for public sector organisations. In policing there is no generally accepted measure of comparative performance. While there are a large number of indicators currently in use there are irreconcilable issues of their validity and reliability. For example, commonly used measures based on crime levels can be affected by the willingness of the public to report crimes, and also different interpretations of counting rules. Fryer et al. (2009) note that the impact of policing on crime levels can be difficult to identify as some policing functions, like crime prevention, are impossible to measure. In January 2014, these questions of validity and reliability resulted in the UK Statistics Authority removing the National Statistics designation from police statistics based on recorded crime data. To account for these problems of validity we must use a perceptual assessment of performance in this study. Perceptual measures based on the manager's or other stakeholder's perception, are common in private sector studies of strategy in the past 20 years. Assessing performance in this way avoids the variation in performance norms and reporting practices which Brews and Hunt (1999) suggest can make objective measures of performance non-viable.

Middle manager divergent activity (MMDA) is a second order latent variable measured using a scale which draws eight items from an original 16 item scale of Floyd and Wooldridge (1997). Eight items from the original scale are not used in this study as they measure integrative activities which relate to the implementation of current organisational strategy and one further item being dropped from the original Floyd and Wooldridge (1992) scale to improve reliability. MMDA comprises two first order latent variables with the 'Championing Alternatives' construct measuring activities related to selling new ideas and initiatives to senior management. The 'Facilitating 
Adaptability' construct measures activities relating to the encouragement of innovative ideas and experimentation by subordinates.

Strategic planning activity (SPA) comprises five items from the 8-item scale used by Bailey et al. (2000) with three items being dropped for scale purification. They are based on the principles of strategy development as a deliberate process involving a structured, logical and rational approach to the organisation and its environment. Strategy in this context involves detailed processes to produce precise plans, with procedures for achieving objectives. Well-defined planning procedures search of solutions to strategic problems, with alternatives meticulously assessed. Strategic options are evaluated against objectives and the analysis of the organisation's environment.

Salience relates to the importance accorded by managers to different stakeholders, and in the context of this study we choose to focus respondents to consider the salience of Community Safety Partnerships (CSPs). They are the most important conduit for collaboration between the police and the other agencies. CSPs are in a unique position relative to the police because of their involvement with and influence on 'policing outcomes'. The role and structure of CSPs is determined from statute and is common to all police forces, which allows comparison of their potential influence. The middle managers involved in the research will have experience of working, or at least communicating, with CSPs as part of their work. Other external stakeholders who could be argued to have an influence on forces are either distant from the middle managers (e.g. the government) or difficult to define and varied between forces (e.g. community groups). The CSP salience (SALCSP) construct is measured with the adaptation of scale previously used by Agle et al. (1999). This scale assesses a manager's perception of the importance of a stakeholder relating to the degree to which they are considered to have power and their claim on organisational attention has legitimacy and urgency.

The use of perceptual measures of strategy development is well established (Hart and Banbury, 1994; Bailey et al., 2000). Collier et al. (2004 p. 70) propose that use of perception measures 
is unavoidable with a large sample and suggest that, 'although perceptions do not always equate with reality, they are more important because they are likely to be the basis of behaviour'. Therefore, perception is a factor in the management involvement in the continual adaptation of plans highlighted as important by Elbanna et al.(2016) in the study of Canadian public sector organisations. For each construct in Strategic planning activity (SPA) and Middle manager divergent activity (MMDA) a 5point Likert-type scale ranging from 'Strongly agree' to 'Strongly disagree' is used. For the CSP salience (SALCRP), a 5-point Likert-type scale is used ranging from 'None at all' to 'Very high'. These scores are averaged for each dimension giving a measure of the extent to which that dimension is present in their organisation. Full details of the survey items is included at Appendix A.

The instruments and methods used in the research were pre-tested on five police forces which covered a range of size, demographics, urban and rural working, with the pilot respondents not included in the final study. Following this initial pre-survey statistical assessment, a sample of thirtysix respondents volunteered to take part in telephone interviews (one per respondent) to explore ease of use, length of the instrument, understandability, and relevance of the ideas being tested.

\section{Data analysis and results}

Structural equation modelling (SEM) using a partial least squares (PLS) approach is used to simultaneously examine the structural components of both the measurement and structural models (Nitzl et al., 2016; Rigdon, 2016; Streukens and Leroi-Werelds, 2016). Despite controversies and debate surrounding PLS, it is now a procedure that is becoming more frequently adopted in strategic management (Hair et al., 2012) and operations management research (Peng and Lai, 2012). SmartPLS version 3 developed by (Ringle et al., 2015) is used. PLS, a variance-based approach, has the advantage over a covariance approach like LISREL or AMOS in that it can be applied to explore 
the underlying theoretical structure of models of 'high complexity but low theoretical information' (Joreskog and Wold, 1982 p.270). In particular, PLS is 'suitable for data analysis during the early stage of theory development' (Tsang, 2002 p. 841). Thus, it is often used to test and validate hypothesised relationships at the theoretical level for evolving models (Cheung et al., 2010; Kristal et al., 2010). In addition, the PLS technique is robust, imposing minimal demand on measurement scales, sample size and residual distributions (Chin, 1998). In fact, 'PLS-SEM is able to reliably estimate very complex models using only few observations without imposing distributional assumptions on the data' (Sarstedt et al., 2014).

[Insert Figure 2 here]

\subsection{Measurement model reliability and validity: Complete model}

A reflective measurement model (see Figure 2) is assessed via its reliability and validity. Three models were subjected to assessment: the complete model and the two subgroups models (HLMM and LLMM). Only the results for the complete model are presented below, however, all the standard benchmarks are satisfied for the other two groups.

Traditional Cronbach's $\alpha$ tends to give an underestimation of reliability (Chin, 1998; Henseler et al., 2009), therefore for all constructs the composite reliability $\rho_{\mathrm{c}}$ developed by Wert, Linn and Joreskog (1974) is calculated with all exceeding the 0.80 threshold (Nunnally and Bernstein, 1994). We examined two aspects of validity: convergent validity and discriminant validity. For all constructs convergent validity, assessed by the average variance extracted (AVE), meets the criterion of 0.5 set by Fornell and Larcker (1981) (See Table 4). Thus, each latent variable explains on average more than $50 \%$ of the variance of its indicators (Gotz et al., 2009). The second order structure for MMDA is assured by the significance of the regression weights at $p<0.001$ and the relatively high $R^{2}$ s (Championing alternatives $87.9 \%$; Facilitating adaptability $86.0 \%$ ), hence championing alternatives (H3a) and facilitating adaptation (H3b) are confirmed as first order constructs of MMDA. 
[Insert Table 4 here]

Discriminant validity is confirmed for all first-order latent constructs, since the square root of each construct's AVE is greater than the bivariate correlation with the other constructs in the model (Chin, 1998a) (see Table 5). Additional support for discriminant validity is established by inspection of the cross-loadings whose magnitudes are lower than those of the main loadings (Chin 1998a).

[Insert Table 5 here]

To assess significance of both the inner weights and outer loadings we executed a bootstrapping estimation procedure with 5000 subsamples following the approach advocated by Hair et al. (2017). All the standardised loadings exceed 0.70 and all are significant $(\mathrm{p}<0.001)$ (see Table 4).

5.2 Structural model: combined groups, HLMM group, LLMM group - evaluation with mediation

To address the observation made by Preacher and Hayes (2008 p. 879) that 'multiple simultaneous mediators have received little attention', our research model embeds SPA in a causal network with SALCSP and MMDA as mediators on its impact on FOP.

The complete model and the two subgroups models of strategic decision makers (HLMM) and operational decision makers (LLMM) were estimated through a bootstrapping procedure to assess $\mathrm{H}_{1}, \mathrm{H}_{2}$ and $\mathrm{H}_{3}$. The results shown on Table 6 , reveal that the total indirect effect $\left(\beta_{2} \mathrm{x} \beta_{3}+\right.$ $\beta_{4} \times \beta_{5}$ ) for the strategic decision makers with a value of 0.089 is significant at the 0.10 level, whereas the total indirect effect for the operational decision makers is not significant. These results lend support to $\mathrm{H}_{1}$ for senior decision makers (HLMM) that strategic planning is associated with force organisational performance. This effect is indirect and mediated both by external stakeholder salience (SALCSP) $\left(\mathrm{H}_{2}\right)$ and middle manager divergent activity (MMDA) $\left(\mathrm{H}_{3}\right)$. In contrast, no support is 
found to support $\mathrm{H} 1$ for lower level middle managers (LLMM) and $\mathrm{H}_{1}$, and therefore $\mathrm{H} 2$ and $\mathrm{H} 3$ is rejected for this level.

Following confirmation of measurement invariance of all constructs a multi-group parametric comparison was examined. The results shown in Table 7 reinforce the conclusion of $\mathrm{H}_{1}$, $\mathrm{H}_{2}$ and $\mathrm{H}_{3}$ for senior managers (HLMM), however the mediating, indirect effect of SPA on FOP is not confirmed for the LLMM group. A summary of the findings is in Table 8 .

\author{
[Insert Table 6 here] \\ [Insert Table 7 here] \\ [Insert Table 8 here]
}

\title{
6. Discussion and conclusions
}

This study responds to the call of Boyne and Gould-Williams (2003) by understanding in more depth the impact of strategic planning on organisations, and the complexity of the link between strategic planning and organisational performance. By choosing a carefully controlled but theoretically pertinent context we extend insight into the value of strategic planning processes in a number of ways. While not dismissing the role of strategic planning in the UK public sector as a means of control and accountability (Llewellyn and Tappin, 2003), this study supports the view that strategic planning activity contributes to organisational performance indirectly. That is, planning appears to facilitate higher level middle managers in playing a more effective strategic role and it gives the processual basis in which relationships with external stakeholders can be made more effective.

In recognising the position of middle managers in strategic planning the study also shows they are heterogeneous. This may be a result of the particular influence of rank in police forces, but the 
findings fit with wider concerns about treating middle managers as one group to assess their strategic behaviour. (Day, 2013) also questions the use of the general term 'middle manager' as such roles and organisational structures have become more varied. Policing serves as an ideal test to discern if middle managers form sub-groups, with the results showing clear differences between the results for HLMM and LLMM. Future studies will therefore need to take care to detail a suitable definition which disaggregates sub-groups of higher and lower level middle managers to test for variance of effect between strategic processes and performance.

Our public services study complements the private sector findings of Rudd et al. (2008) that the impact of strategic planning is indirect, and extend their results to account for simultaneous mediating effects of higher level middle manager divergent activity and external stakeholder salience. It enables us to suggest there is empirical support for the proposition advocated by Kaplan and Beinhocker (2003) who expect the value from strategic planning processes is not derived from the plans produced, but from the impact the process has on the actors involved. We propose this benefit manifests itself in three ways.

First, the rationality of strategic planning can give structure within which middle managers are more willing to engage in divergent activity. Building from Collier et al. (2004) we suggest that middle manager perceptions of the strategy process will influence engagement in it, and this lends support to the conclusions of Andersen (2004) that strategic planning structures can allow influences at lower levels in the organisation (i.e. below the top management team). Middle manager divergent activity can therefore be the source of strategic role conflict (Floyd and Lane, 2000) as managers explore new ideas while at the same time ensuring the current strategy is implemented using planning as a conduit for such activity. Structured strategic planning can create the environment where strategic role conflict is controlled, allowing managers to balance the questioning of existing practices whist experimenting with new ways of working. 
Second, strategic planning can be the basis for external stakeholders to play a stronger role in partnership with the organisation. Varied demands of external stakeholders can be a source of role conflict in managers with strong stakeholders that can constrain the work of managers (Currie, 2000). Structured, rational processes of decision making within the organisation can mitigate that conflict allowing the increased salience of external stakeholders to have a positive impact on working.

Finally, our findings show that structured strategic planning and more autonomous divergent activity takes place at the same time, and they are linked. While strategic planning is often seen as a source of top-down control and structure, its processes could simultaneously facilitate the development of strategic thinking at lower levels of the organisation. This suggests that the principles of planned emergence (Grant, 2003) or guided evolution (Lovas and Ghoshal, 2000) are present in police forces.

\subsection{Implications for practitioners: Process not plans.}

The findings of this study have clear implications for the use of strategic planning in police forces and the strategic role of middle managers and the stakeholders working with police. For police executive leaders, the way that plans are developed and the perception of how strategic decisions are made has an impact on how middle managers in the organisation see their role and engage with external stakeholders. While the value and use of strategic plans as forecasts for future action and performance are questioned the process through which plans are developed influences the work of middle managers. This therefore has implications for the way in which strategic planning processes should be constructed and the wider appraisal of their value.

This study highlights to senior managers that they should have different expectations of involvement from middle managers as they are not homogenous. Middle managers should be divided into sub-groups based on hierarchical rank to assess accurately their role in strategic planning in a 
public-sector context. The reduction in the number of middle managers in police forces in the last 20 years has seen increased responsibility falling on lower level middle managers. This has resulted in inspector and chief inspector levels being accountable for performance and resources which would have previously been the role of a higher-level manager. Despite this, divergent activity of lower level middle management does not have the impact of higher-level colleagues on the planning process. Lower level managers are closer to the day-to-day operations and therefore are in a position for unique insight of strategic issues. Factors which may constrain these officers playing a more strategic role should be looked at by the service if the value of managers at this level is to be realised.

\subsection{Limitations and further research}

The study looks at a particular group of stakeholders who are required to collaborate with police forces. While agencies in the Community Safety Partnerships (CSP) have their own objectives and agenda, this level of collaboration places them in a different position to other external stakeholders with whom police managers may have less influence. Although the CSP was ideal as a proxy for external stakeholder salience future research should explore more generally how strategic planning processes influence varieties of stakeholder relationships and consider how a potential lack of uniformity in other stakeholder groups will influence planning processes.

Although we tested for the moderation effect of tenure in role it was not found to be significant. Other demographic data about respondents was not collected as studies informing our scale design find a variety of potential moderators not to be significant. Future research could re-test moderators, albeit collecting data bout age, gender, length of overall service with the institution, and educational level will need to be judged in relation to the question's likely impact on response rates.

The measurement of organisational performance in the police service is notoriously difficult and to some degree we have chosen to simplify the matter for the purposes of testing the conceptual 
framework with a degree of certainty. This study uses a single perceptual measure of performance, and in an ideal scenario there would be other combinatorial measures of performance which are nonperceptually derived. This overall measure may mask some important details related to operational or financial performance and future research may be able to throw light on this. The changes the police force was undergoing during the time of this study may have impacted the perception of police offers but no systemic error was found. The study happened at a time when the British police service was experiencing change in much the same way as other UK-based public services were experiencing transition. For the context of this study the long-term implications of the introduction of Police and Crime Commissioners was still to be realised, and the government austerity agenda was resulting in reduction in force budgets along with the loss of personnel in middle management. It is possible that this context impacted the perceptions of those involved. The strategic position of middle managers in police forces should continue to be studied as the changes they are facing become embedded.

The differences in results for strategic planning's performance impact between the HLMM and LLMM groupings point to another perspective which is yet to be fully explored in the literature. There is evidence to suggest that middle management involvement in strategic planning has a partially mediating effect in strategy implementation success (Elbanna et al., 2016). If looked at differently the choices made about depth of meaningful engagement in the planning process itself at levels below the top management team and their reporting managers is yet to be explored. Our data suggest the police service planning process does not engage lower level middle managers, either by design, its enactment, or both acting together. It would be useful, given the context of public services where planning is mandated, to explore the different motivations of top management teams in their use of strategic planning, and if they seek to encourage particular forms of involvement. Although there are several studies in the private sector (Boyne and Gould-Williams, 2003; Andrews et al., 2009; Boyne and Walker, 2010; Elbanna et al., 2016) future research could usefully investigate the translation effect through the top management team of strategic planning being enhanced through managerial 
involvement there may be an interesting translation effect through the top management team. By this we mean an internal adjustment of the control or monitoring assumptions behind the strategic planning requirement placed on public service agencies into a process which could have other motivators such as encouraging foresight, building employee commitment, or strengthening accounting-based control.

Although we consider the results to be generalizable to other public-sector organisations, future studies could usefully extend this research to other public-sector bodies to compare results and allow further exploration. 


\section{References}

Agle, B. R., R. K. Mitchell, et al. (1999). "Who matters to CEOs? An investigation of stakeholder attributes and salience, corporate performance, and CEO values." Academy of Management Journal 42: $507-525$.

Andersen, T. J. (2000). "Strategic Planning, Autonomous Actions and Corporate Performance." Long Range Planning 33: 184-200.

Andersen, T. J. (2004). "Integrating Decentralized Strategy Making and Strategic Planning Processes in Dynamic Environments." Journal of Management Studies 41: 1271-1299.

Andrews, R., G. A. Boyne, et al. (2009). "Strategy Formulation, Strategy Content and Performance." Public Management Review 11(1): 1-22.

Ansoff, H. I. (1965). Corporate Strategy. New York, McGraw-Hill.

Armstrong, J. S. and T. S. Overton (1977). "Estimating Nonresponse Bias in Mail Surveys." Journal of Marketing Research 14: 396-402.

Bailey, A., G. Johnson, et al. (2000). "Validation of a Multi-Dimensional Measure of Strategy Development Processes." British Journal of Management 11: 151-162.

Bettis, R. A. and C. K. Prahalad (1995). "The dominant logic: Retrospective and extension." Strategic Management Journal 16: 5-14.

Boyne, G. and J. S. Gould-Williams (2003). "Planning and Performance in Public Organizations." Public Management Review 5: 115-132.

Boyne, G. A. and R. M. Walker (2010). "Strategic Management and Public Service Performance: The Way Ahead." Public Administration Review 70: s185-s192.

Brews, P. and D. Purohit (2007). "Strategic Planning in Unstable Environments." Long Range Planning 40: 64-83.

Brews, P. J. and M. R. Hunt (1999). "Learning to plan and planning to learn: Resolving the planning school/learning school debate." Strategic Management Journal 20: 889-913.

Bryson, J. M. (2004). "What to do when Stakeholders matter." Public Management Review 6: 2153.

Bryson, J. M., B. C. Crosby, et al. (2009). "Understanding Strategic Planning and the Formulation and Implementation of Strategic Plans as a Way of Knowing: The Contributions of Actor-Network Theory." International Public Management Journal 12(2): 172-207.

Bryson, J. M., H. E. Edwards, et al. (2018). "Getting strategic about strategic planning research." Public Management Review 20(3): 317-339.

Burgelman, R. A. (1983). "Corporate Entrepreneurship and Strategic Management: Insights from a Strategy Process." Management Science 29: 1349-1364. 
Burgelman, R. A. (1983). "A Model of the Interaction of Strategic Behavior, Corporate Context, and the Concept of Strategy." Academy of Management Review 8: 61-70.

Burgess, N. and G. Currie (2013). "The Knowledge Brokering Role of the Hybrid Middle Level Manager: the Case of Healthcare." British Journal of Management 24: S132-S142.

Cheung, M.-S., M. B. Myers, et al. (2010). "Does relationship learning lead to relationship value? A cross-national supply chain investigation." Journal of Operations Management 28(6): 482-487.

Chia, R. and B. MacKay (2007). "Post-pocessual challenges for the emerging srategy-as-practice perspective: Discovering strategy in the logic of practice." Human Relations 60(1): 217-242.

Chin, W. W. (1998). The Partial Least Squares approach to Structural Equation Modelling. Modern Methods for Business Research. G. A. Marcoulides. Mahwah, NJ, Lawrence Erlbaum.

Collier, N., F. Fishwick, et al. (2004). "Managerial Involvement and Perceptions of Strategy Process." Long Range Planning 37: 67.

Currie, G. (1999). "The Influence of Middle Managers in the Business Planning Process: A Case Study in the UK NHS." British Journal of Management 10: 141-155.

Currie, G. (2000). "The Role of Middle Managers in Strategic Change in the Public Sector." Public Money \& Management 20: 17.

Currie, G. and S. J. Procter (2005). "The Antecedents of Middle Managers' Strategic Contribution: The Case of a Professional Bureaucracy." Journal of Management Studies 42: 1325-1356.

Day, L. (2013). Who is a Middle Manager - and does it matter? Conference Paper. British Academy of Management. Liverpool.

Dutton, J. E. and S. J. Ashford (1993). "Selling issues to top management." Academy of Management Review 18: 397-428.

Dutton, J. E., S. J. Ashford, et al. (1997). "Reading the wind: How middle managers assess the context for selling issues to top managers." Strategic Management Journal 18: 407-423.

Elbanna, S., R. Andrews, et al. (2016). "Strategic Planning and Implementation Success in Public Service Organizations: Evidence from Canada." Public Management Review 18(7): 1017-1042.

Ezzamel, M. and H. Willmott, Eds. (2007). Critical Management Perspective. Advanced Strategic Management - a Multi-Perspective Approach. Basingstoke, Palgrave Macmillan.

Falshaw, J. R. and K. W. Glaister (2006). "Evidence on formal strategic planning and company performance." Management Decision 44: 9-30.

Ferlie, E. and E. Ongaro (2015). Strategic Management in Public Sector Organisations: Concepts, Schols and Contemporary Issues. New York, Routledge.

Floyd, S. W. and P. J. Lane (2000). "Strategising throughout the organization: Managing role conflict in strategic renewal." Academy of Management Review 25: 154-177. 
Floyd, S. W. and B. Wooldridge (1992). "Middle Management Involvement in Strategy and its Association with Strategic Type: A Research Note." Strategic Management Journal 13: 153-167.

Fornell, C. and D. F. Larcker (1981). "Evaluating Structural Equation Models with Unobservable Variables and Measurement Error." Journal of Marketing Research 18(1): 39-50.

Freeman, R. E. (1984). Strategic management. A stakeholder approach. Boston, Pitman.

Fryer, K., J. Antony, et al. (2009). "Performance management in the public sector." International Journal of Public Sector Management 22: 478-498.

Gotz, O., K. Liehr-Gobbers, et al. (2009). Evaluation of structural equation models using the partial least squares (PLS) approach. Handbook of Partial Least Squares: Concepts Methods and Applications. V. Esposito, W. W. Chin, J. Henseler and H. Wang. Berlin, Springer.

Grant, R. M. (2003). "Strategic planning in a turbulent environment: Evidence from the oil majors." Strategic Management Journal 24: 491-517.

Greenley, G. E., G. J. Hooley, et al. (2004). "Strategic planning differences among different multiple stakeholder orientation profiles." Journal of Strategic Marketing 12: 163-182.

Guth, W. D. and I. C. MacMillan (1986). "Strategy Implementation Versus Middle Management Self-interest." Strategic Management Journal 7: 313-327.

Haberman, C. P. and W. R. King (2011). "The role of research and planning units in law enforcement organizations." Policing 34(4): 687-698.

Hair, J., M. Sarstedt, et al. (2012). "The use of partial least squares structural equation modelling in strategic management research: a review of past practices and recommendations for future applications. ." Long Range Planning 45(5-6): 320-340.

Hair, J. F., M. Hult, et al. (2017). A Primer on Partial Least Squares Structural Equation Modelling (PLS-SEM). Los Angeles, Sage.

Hart, S. and C. Banbury (1994). "How strategy-making processes can make a difference." Strategic Management Journal 15: 251-269.

Henseler, J., C. M. Ringle, et al. (2009). "The use of partial least squares modelling in international marketing." Advances in International Marketing 20: 277-319.

Hogan, J., C. Bennell, et al. (2011). "The Challenges of Moving into Middle Management: Responses from Police Officers." Journal of Police and Criminal Psychology 26(2): 100.

Joreskog, K. G. and H. Wold (1982). The ML and PLS techniques fo modelling with latent variales: Hostprical and comaprative aspects. Systems Under Indirect Observation: Causality, Structure, Prediction, Part 1. K. G. Joreskog and H. Wold. Amsterdam, North-Holland Publishing.

Kaplan, S. and E. D. Beinhocker (2003). "The Real Value of Strategic Planning." MIT Sloan Management Review 44(2): 71-76. 
Kristal, M. M., X. Huang, et al. (2010). "The effect of an ambidextrous supply chain strategy on combative competitive capabilities and business performance." Journal of Operations Management 28(5): 415-429.

Lee, D., M. McGuire, et al. (2018). "Collaboration, strategic plans and government performance: the case of efforts to reduce homelessness." Public Management Review 20(3): 360-376.

Likert, R. (1961). New Patterns of Management. New York, McGraw-Hill.

Llewellyn, S. and E. Tappin (2003). Strategy in the Public Sector: Management in the Wilderness. Journal of Management Studies, Blackwell Publishing Limited. 40: 955-982.

Lovas, B. and S. Ghoshal (2000). "Strategy as guided evolution." Strategic Management Journal 21: 875-896.

Lubans, V. A. and J. M. Edgar (1979). Policing by Objectives. Hartford, Conn., Social Development Corporation.

Mantere, S. (2008). "Role Expectations and Middle Manager Strategic Agency." Journal of Management Studies 45: 294-316.

Mantere, S. and E. Vaara (2008). "On the Problem of Participation in Strategy: A Critical Discursive Perspective." Organization Science 19: 341-358.

Miller, S. (1997). "Implementing Strategic Decisions: Four Key Success Factors." Organization Studies 18(4): 577-602.

Mintzberg, H. (1994). The Rise and Fall of Strategic Planning. London, Prentice Hall.

Mintzberg, H. and J. A. Waters (1985). "Of Strategies, Deliberate and Emergent." Strategic Management Journal 6: 257-272.

Mitchell, R. K., B. R. Agle, et al. (1997). "Toward a theory of stakeholder identification and salience: Defining the principle of who and what really counts." Academy of Management Review 22: $853-886$.

Nitzl, C., J. L. Roldan, et al. (2016). "Mediation analysis in partial least squares path modelling: Helping researchers discuss more sophisticated models." Industrial Management and Data Systems 116(9): 1849-1864.

Nunnally, J. C. and I. Bernstein (1994). Psychometric Theory. New York, McGraw-Hill.

O'Regan, N. and A. Ghobadian (2007). "Formal strategic planning: annual raindance or wheel of success?" Strategic Change 16(1/2): 11-22.

Pappas, J. M. and B. Wooldridge (2007). "Middle Managers' Divergent Strategic Activity: An Investigation of Multiple Measures of Network Centrality." Journal of Management Studies 44: 323-341.

Peng, D. X. and F. Lai (2012). "Using partial least squares in operations management reasearch: A practical guideline and summary of past research." Journal of Operations Management 30(6): 467480. 
Podsakoff, P. M. and D. W. Organ (1986). "Self-Reports in Organisational Research: Problems and Prospects." Journal of Management 12(4).

Preacher, K. J. and A. F. Hayes (2008). "Asymptotic and resampling strategies for assessing and comparing indirect effects in multiple mediator models." 2008 40(3): 879-891.

Rigdon, E. (2016). "Choosing PLS path modelling as analytical method in European management research: A realist perspective." European Management Journal 34(6): 598-605.

Ringle, C. M., S. Wende, et al. (2015). Smart PLS 3. University of Hamburg, Smart PLS GmbH, http://www.smartpls.de.

Rudd, J. M., G. E. Greenley, et al. (2008). "Strategic planning and performance: Extending the debate." Journal of Business Research 61: 99-108.

Rumelt, R. P., D. E. Schendel, et al. (1994). Fundamental issues in strategy: A research agenda. Boston, Harvard Business School Press.

Sarstedt, M., C. Ringle, et al. (2014). "Partial least squares structural equation modelling (PLSSEM): A useful tool for family business researchers." Journal of Family Business Strategy 5(1): 105-115.

Simon, H. A. (1963). The New Science of Management Decision. Englewood Cliffs N.J., Prentice Hall.

Streukens, S. and S. Leroi-Werelds (2016). "Bootstrapping and PLS-SEM: A step-by-step guide to get more out of your bootstrap results." European Management Journal 34(6): 618-632.

Thomas, J. C. and T. H. Poister (2009). "Thinking About Stakeholders of Public Agencies: The Georgia Department of Transportation Stakeholder Audit." Public Organization Review 9: 67-82.

Tsang, E. (2002). "Acquiring knowledge by foreign partners from international joint ventures in a transition economy: Learning-by-doing and learning myopia." Srategic Management Journal 23(9): 835-854.

Venkatraman, N. and V. Ramanujam (1986). Measurement of Business Performance in Strategy Research: A Comparison of Approaches. Academy of Management Review. 11: 801-814.

Wert, C. E., R. L. Linn, et al. (1974). "Intraclass reliability estimates: Testing structural assumptions " Educational and Psychological Measurement 34(11): 25-33.

Whittington, R. and L. Cailluet (2008). "The Crafts of Strategy: Special Issue Introduction by the Guest Editors." Long Range Planning 41(3): 241-247.

Williams, W. and D. Lewis (2008). "Strategic management tools and public sector management." Public Management Review 10: 653-671.

Windsor, D. (1992). Stakeholder management in multinational enterprises. Proceedings of the Third Annual Meeting of the International Association for Business and Society. S. N. Brenner and S. A. Waddock. Leuven, Belgium. 
Wooldridge, B. and S. W. Floyd (1990). "The strategy process, middle management involvement, and organisational performance." Strategic Management Journal 11: 231-241.

Wooldridge, B., T. Schmid, et al. (2008). "The Middle Management Perspective on Strategy

Process: Contributions, Synthesis, and Future Research." Journal of Management 34: 1190-1221. 
Tables

\begin{tabular}{|l|c|}
\hline \multicolumn{1}{|c|}{ Police officer rank } & Organisational level \\
\hline $\begin{array}{l}\text { Chief constable } \\
\text { Deputy chief constable } \\
\text { Assistant chief constable }\end{array}$ & \\
Chief superintendent \\
$\begin{array}{l}\text { Superintendent } \\
\text { Chief inspector } \\
\text { Inspector }\end{array}$ \\
$\begin{array}{l}\text { Sergeant } \\
\text { Constable }\end{array}$ & Executive managers \\
\hline
\end{tabular}

Table 1: England and Wales Police Service ranks (study sample in bold) 


\begin{tabular}{|l|c|c|c|c|c|c|c|}
\hline & N & \multicolumn{3}{|c|}{ Population ('000s) } & \multicolumn{3}{c|}{ Workforce (FTE) } \\
\hline & & Mean & Max. & Min. & Mean & Max. & Min. \\
\hline All PCC forces & 41 & 1,147 & 2,638 & 495 & 4,393 & 12,621 & 1,723 \\
\hline Forces in sample & 17 & 1,157 & 2,638 & 506 & 4,424 & 12,621 & 1,723 \\
\hline
\end{tabular}

Table 2: Comparison of size and population of forces in sample with all forces 


\begin{tabular}{|c|c|c|c|c|c|c|}
\hline & \multicolumn{2}{|c|}{$\begin{array}{c}\text { Total in } 17 \\
\text { participating } \\
\text { forces }\end{array}$} & \multicolumn{3}{|c|}{ Number participating } & $\begin{array}{c}\text { Overall } \\
\text { response } \\
\text { rate }\end{array}$ \\
\hline & $\begin{array}{l}\text { Police } \\
\text { officer }\end{array}$ & $\begin{array}{c}\text { Police } \\
\text { staff }\end{array}$ & $\begin{array}{l}\text { Police } \\
\text { officer }\end{array}$ & $\begin{array}{c}\text { Police } \\
\text { staff }\end{array}$ & $\begin{array}{c}\text { Data } \\
\text { missing }\end{array}$ & $\%$ \\
\hline Inspector or equiv. & 1,730 & 1,321 & 261 & 142 & 4 & 13.4 \\
\hline Chief inspector or equiv. & 501 & 403 & 82 & 80 & 1 & 18.0 \\
\hline Superintendent or equiv. & 245 & 283 & 51 & 35 & - & 16.3 \\
\hline Chief supt. or equiv. & 111 & 96 & 18 & 13 & - & 14.9 \\
\hline Total & 2,587 & 2,103 & 412 & 270 & 5 & 14.7 \\
\hline
\end{tabular}

Table 3: Survey usable responses profile by rank 


\begin{tabular}{|c|c|c|c|c|}
\hline \multicolumn{2}{|c|}{ Measurement Model } & Estimates & T-statistic & $\mathbf{R}^{2}$ \\
\hline \multicolumn{5}{|c|}{ Second-order MMDA Path Coefficient Estimates } \\
\hline $\mathrm{H}_{1 \mathrm{a}}: \mathrm{MMD}$ & $\rightarrow$ Championing Alternatives & 0.9374 & $168.60 * * *$ & 0.879 \\
\hline $\mathrm{H}_{\mathrm{bb}}: \mathrm{MMD}$ & $\rightarrow$ Facilitating Adaptability & 0.9274 & $150.27 * * *$ & 0.860 \\
\hline \multicolumn{5}{|c|}{ First-Order Weights/Loading Estimates } \\
\hline Champion & $\rightarrow$ Cham1_newprojects & $0 . .8616$ & $76.48 * * *$ & \\
\hline Champion & $\rightarrow$ Cham2_meritsofprojects & 0.8422 & $66.45 * * *$ & \\
\hline Champion & $\rightarrow$ Cham3_roleofprojects & 0.8779 & $76.44 * * *$ & \\
\hline \multirow[t]{2}{*}{ Champion } & $\rightarrow$ Cham9_newopportunities & 0.8268 & $59.36 * * *$ & \\
\hline & & & $\begin{array}{r}\rho_{c}=0.9139 \\
A V E=0.7265\end{array}$ & \\
\hline Facilitate & $\rightarrow$ Fac4_experimentalprojects & 0.8522 & $74.00 * * *$ & \\
\hline Facilitate & $\rightarrow$ Fac5_resourceprojects & 0.8702 & $84.42 * * *$ & \\
\hline Facilitate & $\rightarrow$ Fac6_tryoutprojects & 0.8454 & $72.33 * * *$ & \\
\hline \multirow[t]{2}{*}{ Facilitate } & $\rightarrow$ Fac8_relaxproceduresforprojects & 0.7209 & $28.95 * * *$ & \\
\hline & & & $\begin{array}{r}\rho c=0.8940 \\
A V E=0.6795\end{array}$ & \\
\hline SDP & $\rightarrow$ Sda2_preciseplans & 0.7788 & $39.55^{* * *}$ & \\
\hline SDP & $\rightarrow$ Sda11_preciseprocedures & 0.7809 & $38.60 * * *$ & \\
\hline SDP & $\rightarrow$ Sda15_plannedstrategy & 0.7719 & $35.70 * * *$ & \\
\hline SDP & $\rightarrow$ Sda17_precisestregicobjectives & 0.7804 & $33.79 * * *$ & \\
\hline \multirow[t]{2}{*}{ SDP } & $\rightarrow$ Sda23_planningproceduressolutions & 0.7631 & $32.68 * * *$ & \\
\hline & & & $\begin{array}{r}\rho_{c}=0.8827 \\
A V E=0.6007\end{array}$ & \\
\hline SALCRP & $\rightarrow$ legitcrp & 0.6998 & $7.01 * * *$ & \\
\hline SALCRP & $\rightarrow$ powercrp & 0.8264 & $9.42 * * *$ & \\
\hline \multirow[t]{2}{*}{ SALCRP } & $\rightarrow$ urgcrp & 0.7512 & $7.66 * * *$ & \\
\hline & & & $\begin{array}{r}\rho_{c}=0.8042 \\
A V E=0.5790\end{array}$ & \\
\hline
\end{tabular}

$* * * \mathrm{p}<0.001$

Table 4: Measurement model for Strategic Planning Activity: Complete Model 


\begin{tabular}{|l|c|c|c|c|}
\hline & $\begin{array}{c}\text { Championing } \\
\text { Alternatives }\end{array}$ & $\begin{array}{c}\text { Facilitating } \\
\text { Adaptability }\end{array}$ & SPA & SALCSP \\
\hline $\begin{array}{l}\text { Championing } \\
\text { Alternatives }\end{array}$ & $\mathbf{0 . 8 5 2 3}$ & & & \\
\hline $\begin{array}{l}\text { Facilitating } \\
\text { Adaptability }\end{array}$ & 0.7393 & $\mathbf{0 . 8 2 4 3}$ & & \\
\hline SPA & 0.0955 & 0.1100 & $\mathbf{0 . 7 7 5 1}$ & \\
\hline SALCSP & 0.0542 & 0.0237 & 0.2563 & $\mathbf{0 . 7 6 0 9}$ \\
\hline
\end{tabular}

Off diagonals are bivariate correlations, bold main diagonals are square root of corresponding AVE.

Table 5: Discriminant validity of first-order constructs 


\begin{tabular}{|c|c|c|c|}
\hline \multirow[t]{2}{*}{$\begin{array}{l}\text { Groups with Mediation } \\
\text { Paths from Figurel }\end{array}$} & $\begin{array}{l}\text { Combined } \\
\text { Group }\end{array}$ & $\begin{array}{l}\text { Higher Level } \\
\text { Middle } \\
\text { Managers } \\
\text { (HLMM) }\end{array}$ & $\begin{array}{c}\text { Lower level } \\
\text { Middle Managers } \\
\text { (LLMM) }\end{array}$ \\
\hline & $n=687$ & $\mathrm{n}=116$ & $\mathrm{n}=\mathbf{5 7 1}$ \\
\hline \multirow{2}{*}{$\mathrm{SPA} \rightarrow \mathrm{FOP}\left(\boldsymbol{\beta}_{1}\right)$} & $0.300^{* *}$ & $0.196^{* *}$ & $0.319 * *$ \\
\hline & $(7.62)$ & $(2.25)$ & (7.91) \\
\hline \multirow{2}{*}{$\mathrm{SPA} \rightarrow \operatorname{SALCSP}\left(\boldsymbol{\beta}_{2}\right)$} & $0.256^{* *}$ & $0.285^{* *}$ & $0.253 * *$ \\
\hline & $(6.33)$ & $(2.84)$ & $(5.03)$ \\
\hline \multirow{2}{*}{$\mathrm{SALCSP} \rightarrow$ FOP $\left(\boldsymbol{\beta}_{3}\right)$} & 0.058 & $0.273 * *$ & 0.0 .021 \\
\hline & $(1.43)$ & (3.11) & $(0.397)$ \\
\hline \multirow{2}{*}{$\mathrm{SPA} \rightarrow \mathrm{MMDA}\left(\boldsymbol{\beta}_{\mathbf{4}}\right)$} & $0.011 * *$ & $0.256 * *$ & $0.074 *$ \\
\hline & (2.77) & $(2.55)$ & (1.73) \\
\hline \multirow{2}{*}{$\mathrm{MMDA} \rightarrow \mathrm{FOP}(\boldsymbol{\beta} \mathbf{5})$} & 0.055 & 0.013 & 0.0462 \\
\hline & $(1.42)$ & $(0.142)$ & $(0.99)$ \\
\hline \multirow{2}{*}{$\begin{array}{l}\text { Total Indirect Effect } \\
\text { SPA } \rightarrow \text { FOP }\left(\boldsymbol{\beta}_{2} \times \boldsymbol{\beta}_{3}+\boldsymbol{\beta}_{4} \times \boldsymbol{\beta}_{5}\right)\end{array}$} & $0.0205^{*}$ & $0.0809 *$ & 0.0088 \\
\hline & $(1.76)$ & $(1.81)$ & $(0.63)$ \\
\hline
\end{tabular}

${ }^{*} p<0.1 ; * * p<0.05 ; t$-values in parentheses

HLMM Strategic decision makers

LLMM Operational decision makers

Table 6: The Mediating Models 


\begin{tabular}{|c|c|c|c|}
\hline $\begin{array}{c}\text { Total Indirect Effect } \\
\text { Strategic Group }(\text { HLMM })\end{array}$ & $\begin{array}{c}\text { Total Indirect Effect } \\
\text { Operational Group } \\
(\text { LLMM })\end{array}$ & $\begin{array}{c}\text { Difference } \\
\text { |HLMM- } \\
\text { LLMMSG-OG| }\end{array}$ & T-value \\
\hline$\left(\boldsymbol{\beta}_{\mathbf{2}} \mathbf{x} \boldsymbol{\beta}_{\mathbf{3}}+\boldsymbol{\beta}_{\mathbf{4}} \mathbf{x} \boldsymbol{\beta}_{5}\right)=0.0809$ & $\left(\boldsymbol{\beta}_{\mathbf{2}} \mathbf{x} \boldsymbol{\beta}_{\mathbf{3}}+\boldsymbol{\beta}_{\mathbf{4}} \mathbf{x} \boldsymbol{\beta}_{\mathbf{5}}\right)=0.0088$ & 0.0721 & $1.98^{* *}$ \\
\hline$* * p<0.05$
\end{tabular}

Table 7: Multi-Group comparison 


\begin{tabular}{|l|l|l|}
\hline \multicolumn{1}{|c|}{ Hypotheses } & \multicolumn{2}{c|}{ Finding } \\
\hline & \multicolumn{1}{|c|}{ HLMM } & \multicolumn{1}{c|}{ LLMM } \\
\hline H1 - There will be a positive relationship between SPA and FOP & Supported & Not supported \\
\hline H2 -SALCRP will mediate the relationship between SPS and FOP & Supported & Not supported \\
\hline H3 - MMDA will mediate the relationship between SPS and FOP & Supported & Not supported \\
\hline H3a - Championing Alternatives is a first order construct of MMDA & \multicolumn{2}{|c|}{ Supported } \\
\hline H3b - Facilitating Adaptability is a first order construct of MMDA & \multicolumn{2}{c|}{ Supported } \\
\hline
\end{tabular}

Table 8: Summary of hypotheses and findings 
Figures

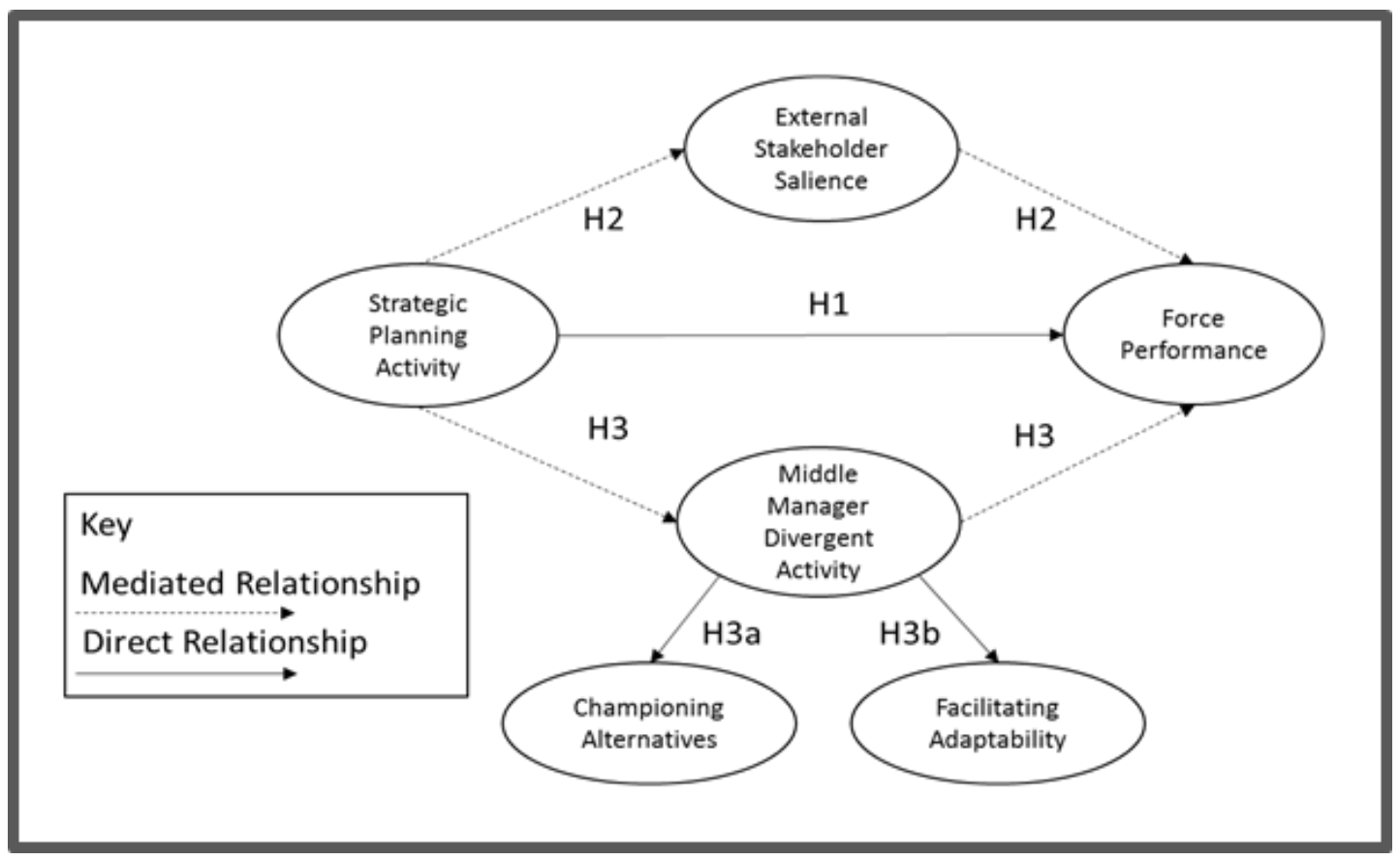

Figure 1: Conceptual framework. 


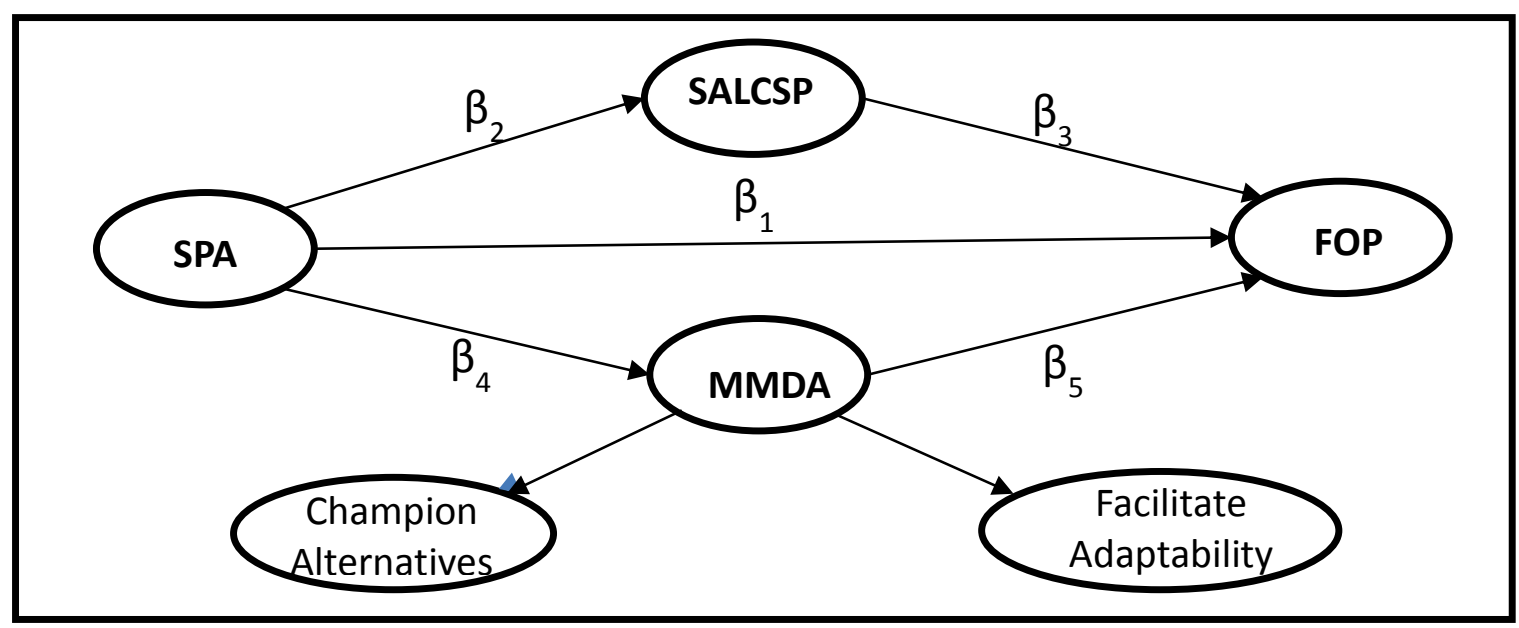

Figure 2: Structural model

Where: SPA = Strategic Planning Activity; MMDA = Middle Management Divergent Activity; SALCSP = External Stakeholder Salience (Community Safety Partnership); FOP = Force Operational Performance 
Appendix 1: Survey instrument constructs, items and their derivation

\begin{tabular}{|c|c|c|c|}
\hline Survey Instrument Item(s) & Mean & SD & Range \\
\hline $\begin{array}{l}\text { FOP } \\
\text { Looking overall, what is your view of the performance of your force } \\
\text { compared to other forces in England and Wales? }\end{array}$ & 3.52 & 0.90 & 5 \\
\hline \multicolumn{4}{|l|}{ SDA } \\
\hline Sdp2 - Our strategy is made explicit in the form of precise plans & 3.34 & 1.23 & 4 \\
\hline Sdp11 - We have precise procedures for achieving strategic objectives & 3.05 & 1.16 & 4 \\
\hline Sdp15 - When we formulate a strategy it is planned in detail & 3.04 & 1.22 & 4 \\
\hline Sdp17 - We have definite and precise strategic objectives & 3.62 & 1.51 & 4 \\
\hline $\begin{array}{l}\text { Sdp23 - We have well-defied planning procedures to search for } \\
\text { solutions to strategic problems }\end{array}$ & 3.06 & 1.14 & 4 \\
\hline \multicolumn{4}{|l|}{ MMDA } \\
\hline \multicolumn{4}{|l|}{ Championing alternatives: } \\
\hline $\begin{array}{l}\text { Champ1 - Put forward new proposals or projects to higher level } \\
\text { managers }\end{array}$ & 3.54 & 0.90 & 4 \\
\hline $\begin{array}{l}\text { Champ2 - Evaluate the merits of proposals generated in your unit, } \\
\text { encouraging and championing some, discouraging others. }\end{array}$ & 3.74 & 0.94 & 4 \\
\hline $\begin{array}{l}\text { Champ3 - Justify and define the role of new proposals to managers above } \\
\text { you }\end{array}$ & 3.50 & 0.92 & 4 \\
\hline $\begin{array}{l}\text { Champ4 - Search for new opportunities and bring them to the attention } \\
\text { of higher-level managers }\end{array}$ & 3.45 & 0.91 & 4 \\
\hline \multicolumn{4}{|l|}{ Facilitating adaptability: } \\
\hline Fac4 - Facilitate experimental proposals being tried in your unit & 3.29 & 0.89 & 4 \\
\hline Fac5 - Locate and provide resources for trial projects & 2.99 & 1.02 & 4 \\
\hline $\begin{array}{l}\text { Fac6 - Present arguments to higher level managers in order to try out } \\
\text { experimental proposals }\end{array}$ & 3.14 & 0.94 & 4 \\
\hline $\begin{array}{ll}\text { Fac8 - } & \text { Relax regulations and procedures in order to get new projects } \\
\text { started }\end{array}$ & 2.78 & 1.07 & 4 \\
\hline \multicolumn{4}{|l|}{ SALCRP } \\
\hline $\begin{array}{l}\text { Powercrp - To what extent do you think that (the CRP) can enforce their } \\
\text { views on the strategies and priorities followed by your force? }\end{array}$ & 2.76 & 1.11 & 4 \\
\hline $\begin{array}{l}\text { Urgcrp - To what extent do you think that (the CRP) demand an } \\
\text { urgent response from your force? }\end{array}$ & 3.47 & 1.09 & 4 \\
\hline $\begin{array}{l}\text { Legitcrp - } \begin{array}{l}\text { To what extent do you think that (the CRP) has a legal or } \\
\text { moral claim for their views to be taken into account. }\end{array}\end{array}$ & 3.72 & 1.04 & 4 \\
\hline
\end{tabular}

